\title{
FAMILY PROTECTION IN SLOVENIA
}

\author{
SUZANA KRALJIĆ
}

\section{Marriage and family are fundamental values of universal human rights}

\subsection{The right to marry in international law}

The Republic of Slovenia is a party to many international and regional human rights instruments. Marriage and family are universal fundamental values and areas of human rights incorporated in many international treaties to which Slovenia is bound:

a) Article 16(1) of the Universal Declaration on Human Rights (1948) ${ }^{1}$ (hereinafter, UDHR): "1. Men and women of full age, without any limitation due to race, nationality, or religion, have the right to marry and to found a family...3. The family is the natural and fundamental group unit of society and is entitled to protection by society and the State.";

b) Article 23(1) of the International Covenant on Civil and Political Rights (1966) ${ }^{2}$ (hereinafter, ICCPR): "1. The family is the natural and fundamental group unit of

1 Uradni list RS, št. 24/2018.

2 Uradni list RS, št. 35/1992 - MP, št. 9/1992.

Suzana Kraljić (2021) Family Protection in Slovenia. In: Tímea Barzó, Barnabás Lenkovics (eds.) Family Protection From a Legal Perspective, pp. 255-286. Budapest-Miskolc, Ferenc Mádl Institute of Comparative Law-Central European Academic Publishing. 
society and is entitled to protection by society and the state. 2 . The right of men and women of marriageable age to marry and to find a family should be recognized.";

c) Article 10(1) of the International Covenant on Economic, Social and Cultural Rights (1966) ${ }^{3}$ (hereinafter, ICESCR): “The States Parties to the present Covenant recognize that: 1 . The widest possible protection and assistance should be accorded to the family, which is the natural and fundamental group unit of society,...";

d) Article 12 of the European Convention on Human Rights (1950) ${ }^{4}$ (hereinafter, ECHR): "Men and women of marriageable age have the right to marry and to find a family, according to the national laws governing the exercise of this right.";

e) Article 9 of the Charter of Fundamental Rights of the European Union (2012) (hereinafter, CFREU): "The right to marry and the right to found a family shall be guaranteed in accordance with the national laws governing the exercise of these rights. ${ }^{"}$ However, the CFREU has taken a step further than Article 12 of the ECHR. The right to marry and the right to start a family in CFREU no longer states "men and women," as this right may also apply to same-sex partners if the national law gives them this right.

\subsection{Symptoms of the European and nation-state crisis and family tendencies}

Since Slovenia became an independent state in 1991, its crude marriage rates (CMRs) have declined. According to the Statistical Office of the Republic of Slovenia, ${ }^{7}$ in 1992, CMRs were 4.6 marriages per 1000 people, while in 2005 they reached their lowest level, at 2.9 marriages per 1000 people. According to the latest data, recorded in 2018, most marriages were recorded after that year, ${ }^{8}$ with CMRs of 3.5 marriages per 1000 people (in 2019, the rate was 3.2). The OECD ranks Slovenia among the countries (Chile, Italy, Luxembourg, and Portugal) with very low CMRs. In contrast, in some other countries (e.g., Lithuania, Turkey), the CMRs per 1000 people are 7 or higher. ${ }^{9}$

On the other hand, the crude divorce rate (CDR) has been quite stable in the last 20 years in Slovenia. CDR in Slovenia was the lowest in 1995 when there were only

3 Uradni list RS, št. 35/1992 - MP, št. 9/1992.

4 Uradni list RS, št. 33/1994.

5 Official Journal C 326, 26.10.2012.

6 Additionally, all international treaties with provisions bearing on the right to marriage can also be found listed in Article 5(d)(iv) of the International Convention on the Elimination of All Forms of Racial Discrimination (Uradni list RS - MP, št. 9/1992 and Article 23(1)(a) of the Convention on the Rights of Persons with Disabilities (Uradni list RS, št. 37/2008).

7 SURS, n.d.

8 SURS, 2020.

9 OECD, 2019. 
0.8 divorces per 1000 people. The divorce rate was the highest in 2005 and 2007 with 1.3 divorces per 1000 people..$^{10}$ Based solely on CDRs, Slovenia belongs among the OECD countries with the lowest CDR. ${ }^{11}$

However, it should be noted that Slovenia is one of the countries with a very high percentage of extra-marital unions. Although it is impossible to give an exact number of extramarital unions in Slovenia, no formalities are required for its formation (comp. Article 4(1) of the FC: "Extra-marital union is a long-lived union of man and woman who have not been married, and there are no reasons that would result in a marriage being invalid. Such a union has the same legal consequences under this Code as if they were married ..."). However, extra-marital unions comprise the fastestgrowing type of family in Slovenia. Their number has increased by 5,500 in the last three years.

One of the critical indicators that extra-marital unions are widespread in Slovenia is the relatively high birth rate of children born out of wedlock. Slovenia ranks in the top three among the EU countries in terms of children born out of wedlock. In 2019, France had the highest number of children born out of wedlock (61 percent), followed by Bulgaria (58.4 percent) and Slovenia (57.7 percent). The nations with the fewest children born out of wedlock were Greece (12.4 percent), Cyprus (20.3 percent in 2017), and Croatia (21.5 percent). ${ }^{12}$

However, the highest rates of children born out of wedlock are recorded in countries that are non-members of the EU: for example, Mexico (69 percent), Iceland (69.4 percent), and Chile (74 percent). In contrast, fewer children are born outside of wedlock in Japan, Korea, and Turkey; their rates are about 2-3 percent. ${ }^{13}$ However, the rate of children born out of wedlock has decreased in recent years in some countries (e.g., in Georgia from 54.4 percent in 2006 to 34 percent in 2019 and in Belarus from 22.7 percent in 2006 to 13 percent in 2018). ${ }^{14}$

\subsection{Causes of the crisis symptoms of marriage and family (possible Eastern European and nation-state special reasons; non-legal and legal reasons)}

The family is still a fundamental social institution that is found in all societies. However, its forms may differ. The reasons for the differentiation of families could have their roots in various factors, such as the historical development of the country, the economic and political situation in the country, the role of men and women in society, and legal provisions concerning the family, as well as individual factors (e.g., employment, marriage, adoption, same-sex relations, property).

10 SURS, n.d.

11 OECD, 2019.

12 EUROSTAT, 2021.

13 OECD, 2020.

14 EUROSTAT, 2021. 
In Slovenia, the family as a fundamental institution still represents one of the most cherished and desired values. The younger generations ( $<35$ years) still see and appreciate the family as a particular value, but not so much marriage. However, over the years, the forms of the family have changed. In the past, as already mentioned, marriage was the main form of family. However, in the last 30 years, families based on extra-marital unions have passed marriage as a traditional family form.

The roots of this change mainly lie in legal regulation, which provides, on the one hand, the equality of all children born in wedlock or outside the wedlock. On the other hand, cohabitants also enjoy the same rights as spouses, not just in family matters (e.g., maintenance, property relations, housing, children) and in all other fields of law (e.g., taxation, pension rights, social transfers, in vitro fertilization procedures).

The reasons for the crisis in marriage and family can be very different. Sometimes it may be a single reason; other times, it may be a given concatenation or conjunction of several reasons.

The reasons can be of a culpable (e.g., adultery, domestic violence) or non-culpable nature (e.g., physical or mental illness). Family and marital life could be influenced by relatives, friends, or even social media. Nevertheless, we should not forget that families and marriages break down because of addiction to work, sports, gambling, wastefulness, or simple non-compliance of the partners.

\section{Non-legal and legal tools of social and state protection of marriage and family}

The family is an important social institution and a natural and fundamental unit of society. Whatever its form (nuclear family, patch-work family, extended family, etc.), every family constitutes an individual different from others. Each family has its characteristics, which may be defined by the members of the family, religion, culture, geographical components, historical background, economic situation, social organization of society, social arrangements, etc.

The principle of institutionality defines marriage as a social and legal institution. The public-law element of a marriage is manifested through state-imposed formality, which is a condition for the validity of a marriage. The social aspect is reflected in the meaning of marriage as a community, which is the usual starting point for forming a family and the community in which the child's protection, education, and training for later independent life are provided. However, as a social institution, marriage also enables spouses to fulfill their needs (emotional and economic security, love, etc.). ${ }^{15}$ 
According to Article 53(2) of the CRS, legal relations within the family shall be regulated by law. The main legal act that regulates family relations is the Family Code. Family policy in Slovenia is based on an integral approach. ${ }^{16}$ The FC provides a broader definition of the family as the living community of the child, regardless of the child's age, with both or one parent or with another adult, provided that the adult person cares for the child and has certain obligations and rights toward the child. Family is thus recognized in the FC as an important social institution that enjoys special protection. Article 2 of the FC is reinforced by Article 3(2) of the FC, which stresses the importance of marriage in conceiving a family. ${ }^{17}$

Although the child's best interest is at the forefront of what is to be secured for the child by the family and parents have autonomy, the state has an interest in controlling this social relationship. The state will intervene in the family as soon as the child's best interests are at stake. It is irrelevant whether this occurs due to the parents' fault or that of other persons who have family ties with the child (e.g., physical abuse, sexual abuse, neglect) or without fault (e.g., mental health problems, illness, death of a parent).

The state's role is more significant today than formerly, as the state is involved in both the formation and dissolution phases of the family. The state can even provide care and education for the child on a subsidiary basis (e.g., by placing the child in an institution) if the parents cannot provide this for the child appropriately. Through its system of differentiated protection (e.g., family, social, penal, health), the state seeks to ensure the best possible conditions for the upbringing and care of the child, primarily within the family. ${ }^{18}$ Only if adequate child protection cannot be guaranteed will the state interfere in the parent-child relationship and in the family.

On February 20, 2018, based on Article 17(1) FC, the Government of the Republic of Slovenia adopted the Resolution on Family Policy 2018-2028, A Family-Friendly Society for All (ReDP18-28)140 (hereinafter, "the Resolution on Family Policy"). The Resolution on Family Policy was prepared by the Ministry of Labour, Family, Social Affairs, and Equal Opportunities in cooperation with other ministries, NGOs, and experts in the field and includes, in particular,

a) Basic orientations and objectives in the field of family policy;

b) Assessment of the situation and identification of key concepts and problems in the field of family policy;

c) Key measures and tasks in the field of family policy, their implementers, and deadlines for their implementation;

d) The data to be collected, processed, integrated, stored, analyzed, and reported in the framework of national statistics, surveys, or opinion polls;

e) The children and family programs; 
f) The definition of monitoring and reporting on the implementation of the resolution;

g) The definition of the indicative level of resources for implementing the measures set out in the resolution and how they will be provided.

In its introduction, the Resolution on family policy emphasizes that, like other countries, Slovenia faces a pluralization of family forms and family lifestyles, changes in parent-child relationships, and changes in partnership relations and family roles. Nevertheless, the family remains a fundamental social institution so important to individuals that it ranks highest in the scale of values in their lives. In 2015, 98 percent of the respondents said that their families were significant to them. Family policy in the Republic of Slovenia is based on a holistic, integral, and inclusive approach. It includes all types of families, considers the plurality of family forms, and the different needs that arise from this, and respects the autonomy of the family and the individuality of its individual members. In particular, it protects the child's rights within the family and beyond, and places the protection and quality of life of families and children at its center. It pursues the best interests of children, who form a special social group entirely dependent on adults and excluded from decision-making because of their age. Children cannot influence their own situation and are highly vulnerable, and therefore need special protection and care. Their situation and circumstances are mainly linked to other persons' situations or living conditions, and above all, of course, their parents. Essential elements of the family policy are aimed at reconciling work and family life, ensuring equal opportunities for both sexes, establishing a wide range of programs and services for families, and contributing to the costs of facilitating the maintenance of children and the protection of families in special circumstances (Resolution on Family Policy, Introduction). Based on various international rankings, indicators, and measurements, Slovenia has achieved a fairly high level of quality of life for families and children.

a) The results of the 2017 survey on the quality of life of children, conducted by the international organization Save the Children, showed that children in Slovenia have the highest quality of life; Slovenia ranked first among 172 countries.

b) According to an indicator illustrating the situation of children, the level of children's risk of poverty and social exclusion, Slovenia was ranked as the country with the fourth-lowest level of risk in 2015.

c) In terms of access to justice for children, Slovenia ranked 20th out of 197 countries in 2016.

d) In terms of fairness for children, Slovenia ranked ninth out of 41 of the world's most developed countries (Resolution, Preface).

The purpose of the Resolution on Family Policy is to identify key objectives and measures for the next 10 years that will further increase the quality of family life, ensure the protection, security, and well-being of families, especially children, and improve the socioeconomic situation of families. The pursuit of the objectives and 
the consistent implementation of the measures could thus create a social context and an enabling environment for decisions to have children. The resolution of family policy has nine equally important priority areas: family support programs, parental care and family benefits, alternative childcare, family welfare, reconciliation of work and family life, labor market and employment, health or health care, upbringing, care, education, and housing.

\section{Dilemmas in the legal protection of marriage and the family}

\subsection{Normative issues}

When the proposal of a new FC was adopted, sensitive issues immediately came to the fore, such as introducing new definitions of family and marriage and the full equality of same-sex partners with spouses. The conservative pole has dealt with the problems of modern families (e.g., the disintegration of the traditional family, the rise of single-parent families, and same-sex unions) by advocating the reassertion of the values of the traditional family. The liberal pole saw these problems as temporary or transitory. It did not believe that the old values were an adequate response to the new modern situation and tended to seek new solutions adapted to the contemporary situation.

A referendum in 2015 was held on the proposal of a new FC. The referendum results led to the retention of the previous definition of marriage and certain restrictions on the rights of same-sex partners. The Civil Unions Act was also adopted in 2016, which brought about the equalization of partners in a civil union with spouses. At the same time, CUA did not grant same-sex partners rights that are certainly among the most desirable, namely the right to marry and the right to joint adoption of a child in Slovenia, nor were they given the right to undergo IVF in Slovenia.

The FC has only been in force for two years. During these two years, there have been no particular trends in Slovenia toward changes in legislation related to marriage and the family.

\subsection{The dilemma about the neutrality of the state and the law and/or legal value creation}

As the referendum results in 2015 were in line with the conservative pole, they feel validated in their aims. The definition of marriage remains traditional ("Marriage is a union of a man and a woman") and same-sex partners cannot marry in Slovenia, though they can enter a civil union or live in a de facto union. Therefore, the Slovenian family law related to the definition of family and marriage still does not stipulate the complete equalization of hetero-and same-sex partners. 


\subsection{Legal recognition, rewarding, and encouragement or avoidance of alternative forms of relationships and family cohabitation}

Despite the traditional definition of marriage in the new FC, Slovenia regulates and recognizes alternative relationships and family cohabitation. As mentioned supra, cohabitation as an alternative form of relationship (marriage) is widespread in Slovenia. Cohabitation is also mentioned in the Slovenian CRS. Article 53(2) of the CRS provides that the law regulates legal relations in an extramarital union (cohabitation). Following the CRS, the new FC defines cohabitation in its Article 4: "An extramarital union is a long-term life community between a man and a woman who have not been married, and there are no reasons why the marriage between them could be invalid. Such a community has the same legal consequences under this Code as if they had been married; in other areas of law, however, such a community has legal consequences if the law so provides."

In 2005, Slovenia adopted its first legal act that regulated some rights and obligations of partners of same-sex registered partnerships. Only registered partnerships enjoyed legal protection. The intention to completely equalize same-sex partners with spouses was not possible; thus, as mentioned, in 2017, the new legal act was adopted. CUA widened the rights and obligations to same-sex partners living in de facto civil unions if they fulfilled the conditions prescribed for valid cohabitation in Article 4 of the FC.

\section{International legal background of the legal protection of marriage and family}

The family as an important social institution and a natural and fundamental unit of society, as well as marriage, is also subject to various international documents, such as soft law and hard law. Slovenia is a contracting party to all important binding international documents (see also Chapter 1, Part 1).

\subsection{Legal protection of marriage and family in Europe and in the law of the European Union}

Several legal instruments have been adopted to unify the legal rules in the area of family law, covering substantive, procedural, and, in particular, conflict-of-law aspects of the legal regulation of this area of family law. This has led to the adoption of several regulations and other acts at the EU level, which, by their very nature, have an impact on the area of family law, for example: 
- Council Resolution of December 4, 1997, on measures to be adopted on the combating of marriages of convenience; ${ }^{19}$

- Council Directive 2003/86/EC of September 22, 2003, on the right to family reunification; ${ }^{20}$

- Council Regulation (EC) No. 4/2009 of December 18, 2008, on jurisdiction, applicable law, recognition and enforcement of decisions and cooperation in matters relating to maintenance obligations; ${ }^{21}$

- Council Regulation (EU) No 1259/2010 of December 20, 2010, implementing enhanced cooperation in the area of the law applicable to divorce and legal separation; ${ }^{22}$

- Charter of Fundamental Rights of the European Union; ${ }^{23}$

- Council Regulation (EU) 2016/1103 of June 24, 2016, implementing enhanced cooperation in the area of jurisdiction, applicable law, and the recognition and enforcement of decisions in matters of matrimonial property regimes; ${ }^{24}$

- Council Regulation (EU) 2016/1104 of June 24, 2016, implementing enhanced cooperation in the area of jurisdiction, applicable law, and the recognition and enforcement of decisions in matters of the property consequences of registered partnerships; ${ }^{25}$

- Council Regulation (EU) 2019/1111 of June 25, 2019, on jurisdiction, the recognition and enforcement of decisions in matrimonial matters and matters of parental responsibility, and on international child abduction. ${ }^{26}$

The ECtHR has also emphasized the importance of the family in various respects. In Marckx v. Belgium, ${ }^{27}$ the ECtHR stressed that the right to live together is an essential component of family life, as it allows family relationships to develop normally. In Berrehab v. the Netherlands ${ }^{28}$ the ECtHR stated that a child born in wedlock is an ipso jure part of that family unit, from the moment and by the very fact of the child's birth. Furthermore, the ECtHR has confirmed the existence of family ties or the right to family life for persons deprived of their liberty (Kurkowski v. Poland ${ }^{29}$ ) and for partners living in a de facto cohabitation (Johnston et al., Ireland ${ }^{30}$ ). The child's best interests dictate that family ties should be maintained, except when the family has proved to be highly unsuitable. Family ties can

19 Official Journal C 382, 16. 12. 1997, pp. 1-3.

20 Official Journal L 338, 23. 12. 2003, pp. 1-29.

21 Official Journal L 7, 10. 1. 2009, pp. 1-79.

22 Official Journal L 343, 29. 12. 2010, pp. 10-16.

23 Official Journal C 326, 26. 10. 2012, pp. 391-407.

24 Official Journal L 183, 8. 7. 2016, pp. 1-29.

25 Official Journal L 183, 8. 7. 2016, pp. 30-56.

26 Official Journal L 178, 2.7.2019, pp. 1-115.

27 Marckx v. Belgium (app. no. 6833/74), 13 June 1979.

28 Berrehab $v$. the Netherlands (app. no. 10730/84), 21 June 1988.

29 Kurkowski v. Poland (app. no. 36228/06), 9 July 2013.

30 Johnston and others v. Ireland (app. no. 9697/82), 18 December 1986. 
be severed only in exceptional circumstances, and every effort must be made to preserve personal relationships and, if and when appropriate, to restore the family (Gnahoré v. France ${ }^{31}$ ).

The ECtHR has also considered that, in the absence of natural parents, family ties also exist between uncle/aunt and nephew/niece (Butt v. Norway ${ }^{32}$; Jucius and Juciuviene v. Lithuania ${ }^{33}$ ). However, in normal circumstances, the relationship between grandparents and grandchildren is different. Legal protection is lower than that enjoyed by the parent-child relationship (Kruškić v. Croatia ${ }^{34}$; Mitovi v. the former Yugoslav Republic of Macedonia ${ }^{35}$ ). From the ECtHR cases cited above, we can conclude that the definition of family and family ties is broad. It is not limited to parents as holders of parental care, but extends in individual cases to other relatives or family members. However, Article 8 of the ECHR only guarantees the right to respect private and family life, but not the right to find a family or the right to adopt. The right to respect for family life does not protect the desire to find a family. Still, it presupposes the existence of a family, or at least the presence of a potential relationship between particular persons, such as between a child born out of wedlock and his father, or between a child and his father, even if it later turns out that there is no biological link between them (Paradiso and Campanelli $v$. Italy $\left.^{36}\right)$. However, the ECtHR has also recognized the right to private and family life for same-sex couples (Vallianatos et al. v. Greece ${ }^{37}$; Oliari et al. v. Italy ${ }^{38}$; Orlandi et al. v. Italy ${ }^{39}$.

\subsection{The appearance of international and European norms in the national constitutions and legal systems}

The constitutional legal basis of marriage is Article 53(1) of the Constitution of the Republic of Slovenia ${ }^{40}$ (CRS). Article 53(1) of the CRS states that marriage shall be based on the equality of the spouses and shall be solemnized before an empowered state authority. Unlike other constitutions (for example, Croatia [comp. Article 61(2) of the Croatian Constitution: "Marriage is a living union between a woman and a man"); Hungary (comp. Article L(1) of the Hungarian Constitution: "Hungary shall protect the institution of marriage as the union of a man and a woman..."); Serbia

31 Gnahoré v. France (app. no. 40031/98), 17 January 2001.

32 Butt v. Norway (app. no. 47017/09), 4 March 2013.

33 Jucius and Juciuviene v. Lithuania (app. no. 14414/03), 25 February 2009.

34 Kruškić v. Croatia (app. no. 10140/13), 25 November 2014.

35 Mitovi v. the former Yugoslav Republic of Macedonia (app. no. 53565/13), 16 July 2015.

36 Paradiso and Campanelli v. Italy (app. no. 25358/12), 24 January 2017.

37 Vallianatos and others v. Greece (app. no 29381/09 in 32684/09), 7 November 2013.

38 Oliari and others $v$. Italy (app. no. 18766/11 in 36030/11), 21 July 2015.

39 Orlandi and others $v$. Italy (app. no. 26431/12), 14 December 2017.

40 Uradni list RS, št. 33/91-I, 42/97 - UZS68, 66/00 - UZ80, 24/03 - UZ3a, 47, 68, 69/04 - UZ14, 69/04 - UZ43, 69/04 - UZ50, 68/06 - UZ121,140,143, 47/13 - UZ148, 47/13 - UZ90,97,99, 75/16 UZ70a. 
(comp. Article 62(2) of the Serbian Constitution: "Marriage shall be entered into based on the free consent of man and woman before the state body"), the CRS emphasizes the equality of spouses but does not assume gender diversity of the spouses. Some other constitutions define marriage through equality of the spouses (e.g., see Article 31(1-2) of the Constitution of Kosovo: "1. Based on free will, everyone enjoys the right to marry and the right to have a family, as provided by law. 2. Marriage and divorce are regulated by law and are based on the equality of spouses"; Article 32(1) of the Constitution of Spain: "1. Managers and women have the right to marry full legal equality"; and Article 29(2) of the Italian Constitution: "Marriage is based on the moral and legal equality of the spouses within the limits laid down by law to guarantee the unity of the family").

\subsection{Protection of marriage and family as fundamental rights and values in the practice of national constitutional courts}

The constitutional legal basis of marriage is laid down in Article 53 of the CRS. Article 53(1) of the CRS states that marriage shall be based on the equality of the spouses and that it shall be solemnized before the competent state authority. The equality of the spouses is reflected in the relationship between the spouses themselves, as in the relationship of the spouses/parents to their common children.

The fact that the CRS already provides for marriage to be solemnized before a state authority demonstrates the state's interest in marriage. Two persons (man and woman) will only enjoy rights and obligations as spouses if the marriage is solemnized before a state authority consisting of:

a) a registrar and head of the administrative unit or a person authorized by the head (Article 33(1) of the FC);

b) a registrar and the mayor of the municipality in which the marriage should be solemnized (Article 33(2) of the FC);

c) or just a registrar (Article 38 of the FC).

All the named options are a forma ad solemnitatem, since a deviation from the prescribed formality means that such a marriage does not exist and has no legal consequences (Art. 42 of the FC). In such a situation, the public prosecutor can file a proposal for a declaration that marriage does not exist. This also shows that the state has an interest in marriage. The jurisdiction for matrimonial maters (e.g., dissolution of marriage) has occurred since 2019 in non-contentious courts.

Article 53(2) of the CRS provides that marriage and the legal relationships within it, the family, and the extramarital union shall be governed by law. The law governing marriage and the legal relationships within it, the family and cohabitation, is the FC. In addition, several other legal acts contain provisions that interfere with family law relations (e.g., Domestic Violence Act, the Criminal Code, the Provision of Foster Care Act, and the Non-Contentious Civil Procedure Act). 


\subsection{Separation and cooperation of the state and churches in the protection of marriage and the family}

Article 7(1) of the CRS states that the state and religious communities are separated. On the other hand, Article 53 of the CRS provides that marriage shall be solemnized before a competent state authority (see supra). Following Article 7(1) and Article 53 of the CRS, only so-called civil marriage is recognized in Slovenia. In Croatia, however, it is left to the future spouses to choose between two alternatives: whether to marry before a state authority (civil marriage) or before a religious community (religious marriage) that has the competence to solemnize marriages following the Croatian Family Code. A marriage in the religious form, but with the effect of civil marriage (dualist system), may be contracted before the official of a religious community that has a legal relationship with the Republic of Croatia on the matter (Article 13(3) of the Croatian Family Code). When a marriage solemnized before a religious community produces civil effects, it is a so-called concordant marriage. However, since the separation of state and religious communities is consistently applied in Slovenia, only a marriage contracted before a state authority (a socalled civil marriage) produces civil effects under civil law. However, it is left to the spouses to confirm their marriage before an official religious community (so-called religious marriage). ${ }^{41}$

\subsection{Civil society (non-governmental) bodies and institutions for the protection of marriage and the family}

FC contains some general provisions that address the role of non-governmental organizations in the protection of marriage and family.

Article 5(5) of the CPR provides that the state shall ensure the conditions for the activities of non-governmental organizations and professional institutions for the development of positive parenting.

Social work centers and other public authorities, public service providers, state and judicial authorities, local authorities, humanitarian organizations, and other non-governmental organizations must cooperate in carrying out FC tasks (Article 16 of the FC).

State bodies, bodies of self-governing local communities, holders of public powers, providers of public services, and non-governmental organizations that, in the course of their work, become aware of circumstances from which it may be concluded that a child is at risk, shall immediately inform the competent social work center or court (Article 180(1) of the FC)).

A non-governmental organization working in the field of family policy may be granted the status of a non-governmental organization in the public interest following the law regulating the status of non-governmental organizations in the public 
interest. The status of a non-governmental organization in the public interest shall be granted to a non-governmental organization if its activities contribute to the development of family policy and if it continuously carries out activities that positively affect the functioning and development of families (Article 281 of the FC).

\subsection{State institutions for marriage and family protection}

Family policy in the Republic of Slovenia is based on an integral and inclusive approach, promotes positive social values, and follows the general principles (inclusion, equality, protection, safeguarding, and respect) of:

a) inclusion of the whole population or orientation toward all families;

b) respect for the plurality of family forms and the different needs that arise therefrom;

c) respect for the autonomy of the family and the individuality of its members;

d) protection of children's rights in the family and society and concern for the quality of children's lives;

e) promotion of equal opportunities for both sexes;

f) contribution by the state to the cost of supporting children;

g) positive discrimination against the most vulnerable families;

h) consistency of measures with the perceived needs of the population;

i) generality of family policy measures (Resolution on Family Policy, 1.2. Fundamental Principles).

Monitoring the implementation and realization of the set objectives in light of the basic principles of the Resolution on Family Policy is the duty of all ministries, which are the promoters of individual measures. Once a year, all ministries submit a report on the realization of the objectives and the implementation of the measures to the Council of the Republic of Slovenia for Children and Family, and as part of the regular annual reporting to the Government of the Republic of Slovenia they also include a report on the realization of the Resolution on Family Policy in the report on the implementation of the resolution (Resolution on Family Policy, 1.4. Monitoring the Implementation of the Resolution and Reporting).

The state's role is more significant today than it used to be, as the state is involved in both the formation and dissolution phases of the family. The state can even provide care and education for the child on a subsidiary basis (e.g., by placing the child in an institution) if the parents cannot provide this for the child in an appropriate way. The state tries to ensure through a system of differentiated protection (e.g., family, social, penal, health) the best possible conditions for the upbringing and care of the child, primarily within the child's family. If after a gradual implementation of protective measures, starting with the least restrictive, adequate protection of the child's best interests still cannot be assured, the state will through its authorities (e.g., courts, social work center, police) interfere in the parent-child relationship. 
Slovenian social work centers play a crucial role in protecting marriages and families. Their roles are essentially twofold. On the one hand, they have a supervisory role, and on the other an advisory role. In the first role, they supervise the performance of certain family matters (e.g., guardianship and foster care). In the second, they have the ability to assist the court by giving opinions to help the court in decision-making (e.g., on the allocation of the child, on the best interests of the child). In some matters, the social work center can appear as the initiator of the procedure (e.g., adoption, guardianship). ${ }^{42}$

The social work center also plays an important role in divorce. Before filing a proposal for a contested or uncontested divorce, the spouses will attend preliminary counseling with the social work center, unless:

a) they have no children in common over whom they have parental care;

b) one of the spouses is incapable of reasoning;

c) one of the spouses has an unknown place of residence or is missing;

d) one or both spouses live abroad.

The preliminary counseling aims to help the spouses determine whether their relationship has deteriorated or whether it is possible to preserve the marriage. The deterioration of marriage should be so extreme that marriage has become unbearable for at least one of them. The spouses shall attend preliminary counseling in person without a proxy (Article 200 of the FC).

The parents must also attend the preliminary counseling before they propose to the court to decide on the child's custody, maintenance, and contact with them or other persons or on issues relating to the exercise of parental care, which have a significant impact on the child's development. There will be no preliminary consultation if one of the parents is inconsistent or lives abroad, is missing, or has unknown residence (Article 203 of the FC).

The regulation of family mediation in FCs also represents innovation. Mediation was an alternative dispute resolution used in family matters before the FC, but was not regulated in the previous Marriage and Family Relations Act. Mediation can occur before, during, or after court proceedings. A mediator should help spouses or parents to regulate personal and property issues (Article 205(1) of the FC).

Article 153 of the FC gives general authorization to the court and the social work center to take all necessary actions and measures required for the upbringing and protection of the child or the protection of the child's property and other rights and interests.

Before the court decides on a measure of a more permanent nature, the social work center draws up a family and child assistance plan. The assistance plan shall contain a description of the situation, the needs of the children, the possibilities of the family, the method of monitoring, the forms of assistance, and a description of the implementation of the measure. The social work center may include in the 
family and child assistance plan a family therapy program, psychiatric treatment, treatment for alcohol or illicit drug dependence and other health, educational and psychosocial programs if it appears that the parents would be able to resume the child's upbringing and care after the therapy or treatment, or in other cases where it is in the best interests of the child (Article 170 of the FC).

\section{Determination of the notion of "family"}

The Slovenian FC adopts a broader definition of the family. Family is defined as the living community of a child without regard for the child's age, with both (e.g., a nuclear family) or one parent (e.g., a single-parent family) or with another adult (e.g., a foster family or a patch-work family), if this adult person cares for the child and has certain obligations and rights toward the child. The child is the central subject of the family. Therefore, the family enjoys special protection from the state. According to the priority principle, parents are responsible for protecting the child and the child's best interests. However, circumstances may arise that could entail the derogation from this principle (e.g., deprivation of parental care and removal of the child). The FC introduced important innovations. Following Article 231 of the FC, the court may grant parental care to a relative for a child without living parents if doing so is in the child's best interest. The relative must be willing to take responsibility for the granted parental care and fulfill the conditions prescribed for the child's adoption. The relative to whom the court will grant parental care is also responsible for the child's care and upbringing. Therefore, a family is formed between them.

A precise definition of the family is almost impossible, as family relationships are rapidly changing. New forms of family are emerging that were unknown or not legally regulated in the past or were not covered by the concept of family (e.g., a family based on parents living outside of marriage did not enjoy legal protection, nor did a same-sex family). ${ }^{43}$ This makes it difficult for modern law to define the family, and as a result, modern family laws avoid specific definitions of the family for this reason. However, lawyers have mainly defined the family in two ways: descriptively (by listing the members of which the family is composed) and operationally (by listing the functions that the family performs). ${ }^{44}$ From the above, it can be concluded that the FC has combined the two ways of describing the family by listing the persons (but not exhaustively) in the first part and the functions of the family in the second part. ${ }^{45}$ 


\section{The definition of marriage}

Article 3 of the FC defines marriage traditionally: "(1) Marriage is the union of husband and wife,..." Following the adoption of the new FC, marriage can only be between a man and a woman, but not by same-sex partners.

The Civil Unions Act, adopted in 2016, introduced a new term, namely civil union, replacing the term of registered same-sex civil partnership, which was regulated in the previous Act on Registered Same-Sex Partnerships. In Article 2(1), CUA defines a civil union as a living union between two women or two men. The CUA governs the entry, legal consequences, and dissolution of civil unions. Therefore, there is a clear distinction between marriage, which under the FC can be entered into by two persons of different sexes, and civil unions, which can be entered into by two persons of the same sex, that is, two women or two men. FC and CPA have in common that both legal acts are based on the principle of monogamy.

In addition to marriage and civil unions, Slovenia also regulates cohabitation and de facto civil unions.

\section{Protection of marriage and family at the level of family law principles}

For this purpose, different legal acts define a different range of family members. Article 2 of the Domestic Violence Act ${ }^{46}$ ( DVA) listed the following persons as relatives:

a) a spouse or extramarital partner;

b) a relative in the direct line (e.g., grandfather/grandmother, grandson/granddaughter, father/mother, son/daughter, etc.);

c) a relative in a collateral line up to the fourth grade (cousins, aunts/uncles, nephews/nieces, brothers/sisters-the same applies to half-siblings);

d) a person/relative by affinity in a direct line (father-in-law/mother-in-law, son-in-law/daughter-in-law);

e) a person/relative by affinity in a collateral line up to and including the second degree (brother-in-law/sister-in-law);

f) an adoptive parent and an adopted child;

g) a foster parent and a child placed in a foster family;

h) a guardian and a ward;

i) persons who have a child in common;

j) persons living in the same household;

46 Zakon o preprečevanju nasilja v družini (Domestic Violence Act (DVA): Uradni list RS, št. 16/08, 68/16, 54/17 - ZSV-H. 
k) persons who are in a partnership relationship, whether living in the same household.

The persons listed above are considered family members under the DVA, even if the relationship or partnership has ended. A new spouse, extramarital partner, a partner in a civil union or partner in a de facto civil union, a family member (stepfather/stepmother), or a child of one of the listed family members (stepchild) is also considered a family member under the DVA.

The DVA is an essential legal act to protect the best interests of the child. DVA provides that the child enjoys special protection against violence. A child is also a victim of violence if the child is present when violence is perpetrated against another family member or lives in an environment where violence is perpetrated (Article 4(1-2) of the DVA). Article 6 of the DVA sets out a duty to report. Comparing Article 6 of the DVA (duty to report) and Article 180 of the FC (duty to inform), we can see that both legal acts address the same subjects. However, the difference is in the subject matter of information. The FC is broader in this respect, referring to "circumstances from which it may be inferred that a child is at risk." In contrast, the DVA is narrower, referring to "circumstances from which it may be inferred that violence is being committed."

\section{Marriage as the smallest basic unit of the family}

Under Article 3(1) of the FC, marriage is the union of the husband and wife. Article 3(2) of the FC states that the meaning of marriage is the conception of the family. However, the modern dynamics of everyday life (e.g., increasing life expectancy) and the interests of individuals who may not desire to procreate also dictate the possibility of a different meaning of marriage.

Older people who marry (usually) do not intend to produce offspring but want to ensure, through marriage, that they can grow old securely with a person for whom they have feelings of affection. Accordingly, the legislator has supplemented Article 20(2)(3) of the FC to extend the primary aim of marriage. Thus, marriage is based on the spouses' free choice to marry, mutual emotional attachment, mutual respect, understanding, trust, and mutual assistance. All of the above is the basis of the obligations between the spouses (Article 56 of the FC).

A living community between spouses can exist even if the spouses live apart for legitimate reasons (e.g., working or studying abroad). On the other hand, purely living together does not guarantee the fulfillment and satisfaction of the emotional, psychological, sexual, procreative, economic, cultural, and other needs of the spouses that otherwise form the core of the spouses' living community. Although the legislator has expressly provided that marriage should be based on mutual emotional attachment, mutual respect, understanding, trust, and mutual assistance (cf. Article 20 
in conjunction with Article 56 of the FC), which constitutes the basis of the mutual relations between the spouses, in the event of a deviation, the other spouse cannot be forced to emotional attachment to his or her spouse, respect him or her, understand and trust each other, and assist each other.

The existence of marriage or an extramarital union is not excluded even in the case of domestic violence between spouses or cohabiting partners. Therefore, the presence of domestic violence may preclude mutual cohesion, emotional attachment, understanding and respect, and mutual assistance. However, following the principle of autonomy, the spouse or cohabiting partner has to decide whether he or she wishes to end or remain in such a partnership.

\section{Other legally recognized forms of partnership}

Marriage is a legal institution in all states, but there are differences in legal regulations. However, the situation concerning same-sex partnerships differs. There are various forms of legal recognition of same-sex partnerships throughout the world, including marriage, registered partnerships/civil unions, cohabitations/de facto civil union, or even no regulation. Slovenia, Croatia, Hungary, Czech Republic, Slovakia, Poland, Estonia, Latvia, Lithuania, Bulgaria, and Romania have a common history of socialist systems as part of the communist bloc. Therefore, in the last 30 years, all the forenamed countries have been faced with political changes, new legislation, and transitional problems. In many of them, religion still plays an essential role in everyday life and is related to legal questions or regulations of same-sex partnerships. Marriage as a "traditional value and partnership relation" is still very strongly represented in some countries. ${ }^{47}$ Some EU countries regulate the legal registration and recognition of same-sex partnerships, but none of them enables the right to marry. Such regulation deliberately separates marriage from a registered same-sex partnership/ civil union. On the other hand, in some countries, same-sex partners have almost the same rights and obligations as the spouse in the marriage (e.g., Slovenia).

Currently, partners from same-sex civil unions in Slovenia have all but three of the rights and obligations that come with marriage: They cannot enter into marriage, jointly adopt a child, or use the system of in vitro fertilization (Article 2(3) and 3(4) of the CPA). The right to marry is recognized for same-sex partners in $13 \mathrm{EU}$ countries $^{48}$ : the Netherlands (since 2001), Belgium (2003), Spain (2005), Sweden (2009), Portugal (2010), Denmark (2012), France (2013), Luxembourg (2015), Ireland (2015), Finland (2017), Malta (2017), Germany (2017), and Austria (2018). ${ }^{49}$

47 Kraljić, 2017, p. 56.

48 Status as of April 2021.

49 European Union, 2020. 
As mentioned above, the new Slovenian family code ${ }^{50}$ was rejected by the referendum on March 25, 2012. Therefore, on March 3, 2015, the Slovenian Parliament amended the Slovenian Marriage and Family Relations Act with a new redefinition of marriage based on gender equality. The redefinition of marriage also made it possible for same-sex partners to conclude a marriage. The new definition of marriage (also cohabitation) affected adoption and afforded same-sex couples the right to contract a marriage. Therefore, discrimination based on sex orientation was eliminated. However, the bill was rejected on the referendum on December 20, 2015 (voters voted against, with 63.47 percent of a turnout of 36.38 percent). One day after the referendum on December 20, 2015, the CUA was passed to the National Assembly, which adopted CUA on April 21, 2016, with 54 votes in favor and 15 against. CUA does not regulate family relations or relations with third persons (also not regarding children).

\section{The relation and connection of extramarital relationships to family and marriage}

Slovenia is one of the countries with a liberal approach to the legal regulation of cohabitation. Cohabitation entails rights and obligations equal to those of marriage. The legal regulation of the consequences of cohabitation has a history of several decades in Slovenia. The earliest legal act recognizing the legal status of cohabitants is the Yugoslav Law on Workers' Insurance, ${ }^{51}$ dating back to 1922 . This act allowed the cohabiting partner of a deceased worker to obtain material support if she had lived with him for at least one year, and if a child had been born to them during the cohabitation. Both these conditions had to be cumulatively satisfied.

In 1976, the Marriage and Family Relations Act was adopted, explicitly including cohabitation among the legislative provisions. Thus, cohabitation was placed alongside marriage. The social meaning of marriage was the conception of the family (Article 3(2)(3) of the Marriage and Family Relations Act). However, a family can also be created in an extramarital union, as a relationship between parents and children.

In 1991, the extramarital union was also given a constitutional dimension. Article 53(2) of the CRS expressly stipulates that legal relations in an extramarital union shall be regulated by law.

According to Article 4(1) of the FC, an extramarital union or cohabitation is considered a long-term living union between a man and a woman who have not

50 The bill of Family Code defined marriage as a union between a man and a woman and stipulated that same-sex partners should have all rights of marriage except joint adoption.

51 Uradni list Kraljevine Jugoslavije, št. 117/1922. 
entered into a marriage, where there are no grounds for a marriage between them to be invalid. Such a union shall have the same legal consequences for the relationship between them under the CUA as if they had entered a marriage. However, in other areas of law, such a union has legal consequences if the law so provides.

However, in 2016, the CUA introduced an additional innovation by granting legal validity to a same-sex de facto civil union in addition to a "registered" civil union. In its definition of a de facto civil union, the CUA is aligned with Article 3(1) of the FC. A de facto civil union is a long-term living union between two women or two men who have not entered into a civil union, and there are no grounds for a civil union between them to be invalid. A de facto civil union has the same legal consequences under the CUA in the relationship between partners as if they had entered into a civil union. A de facto civil union shall also have the same legal consequences as a civil union in those areas of law where a civil union has legal consequences, unless the CPA provides otherwise.

If a decision on a right or obligation depends on the existence of a cohabitation (either a de facto civil union or an extramarital union), the decision on that question has a legal effect only in the matter for which that question was decided (Article 4(2) of the of the FC and Article 3(3) of the CPA).

The essential difference between an extramarital union and a de facto civil union is given in the limitations of Article 3(4) of the CPA, which stipulates that the partners of a de facto civil union cannot adopt a child together and that they are not entitled to undergo assisted reproduction procedures by biomedical means.

The following is a description of the preconditions that must be fulfilled for the cohabitation to enjoy legal protection and for legal consequences, that is, rights and obligations, to arise between partners. All of the above also applies to a de facto civil union. These differences are highlighted.

Temporal condition: The FC stipulates that the extramarital union must last for a long time. The FC does not specify how long an extramarital union must exist to produce legal effects under the FC. Whether a particular situation gives rise to a long cohabitation will be determined by the court on a case-by-case basis, and thus the court will have to answer whether cohabitation has lasted for a long time, though it should be long enough to create a similarity between an extramarital union and the community of life present during marriage. In each case, the court will consider all the relevant circumstances (e.g., actual duration, duration, possible birth of a child).

Personal condition: Under the FC, only the living union between a man and a woman is legally recognized. Therefore, an extramarital union is based on the gender diversity of the partners. However, under the CPA, a de facto civil union can be contracted between two men or two women.

Substantive conditions: Both the FC and the CPA stipulate the existence of a living community as a fundamental prerequisite for the validity of an extramarital union and a de facto civil union (cf. Article 4(1) of the FC and Article 3(1) of the CPA). However, the legislator has not specified what constitutes a living community. The 
living community is a legal standard to be filled in by the court on a case-by-case basis. The cohabitation of cohabiting partners or partners in a de facto civil union must constitute a living community in the physical-natural, moral-spiritual, sexual, and economic sense. The common household of cohabiting partners is the most visible sign to the surrounding community that a living community exists between a man and a woman. Living together or sharing a household is therefore an essential element of cohabitation. The obligation to live together is judged more strictly in cohabitation matters than in marriage, as it is the only outwardly visible sign that cohabitation exists. In certain cases, cohabitation is presumed to exist despite the separation. The reasons for living apart must be justified (e.g., if one of the cohabiting partners is working abroad, military service, school, etc.). ${ }^{52}$

Material condition: The fourth constitutive element of a legally recognized cohabitation/extramarital union (including a de facto civil union) is the absence of grounds that would render marriage between the partners invalid. Persons wishing to enter into a valid extramarital union (a man and a woman) or a de facto civil union (two men or two women) must fulfill the conditions for marriage (e.g., free consent, monogamy, kinship, marriageable age).

According to the FC, the legal consequences of cohabitation between partners (male and female) have the same legal consequences under the FC in the relationship between them as if they had entered into a marriage. In other areas of law, a sectoral law is provided. The introduction of extramarital union into the Slovenian CRS in 1991 led to a proliferation of laws placing extramarital partners on an equal stage with spouses regarding rights and obligations. There is a notable difference between older and newer laws. Older laws provide for the recognition of specific rights, while more contemporary laws start from the general premise of equality of rights and obligations of spouses and cohabitants.

Children born or conceived out of wedlock are not subject to a legal presumption of paternity, and therefore the institution of recognition or even judicial establishment of paternity is applicable. However, the FC is an exception to this general rule. In Article 133, the FC extends the legal presumption of paternity to the extramarital partner (not to the partner of a de facto civil union!). The father of a child conceived by biomedical assistance is deemed to be the mother's husband or her extramarital partner, provided that he has given his consent to the procedure following the Infertility Treatment and Procedures of Biomedically Assisted Procreation Act (hereinafter, "Infertility Act"). ${ }^{53}$ The exception is based on prior consent that the extramarital partner must provide assisted procreation or conception through biomedical assistance. The paternity of the person who is presumed to be the child's father may not be contested, except on the grounds that the child was not conceived by means of a procedure of assisted reproduction (Art. 133(1-2) of the FC). Since

52 Kraljić, 2019, p. 53.

53 Zakon o zdravljenju neplodnosti in postopkih oploditve z biomedicinsko pomočjo: Uradni list RS, št. 70/00, 15/17 - DZ. 
the partners of a civil union, whether or not contracted, are not eligible for assisted reproduction procedures (cf. Article 2(3) and Article 3(4) of the CPA), the legal presumption in Article 133(1) of the FC does not extend or apply to them.

\section{Legally recognized forms of kin family relationships}

\subsection{Presumptions for determining paternity status}

The child's mother's husband is considered to be the father of the child born in wedlock (Article 113(1) of the FC). The legal presumption of paternity has roots in Roman law. ${ }^{54}$ While maternity could be linked to childbirth, which someone usually witnessed, paternity was long considered to be impossible to establish with certainty. Therefore, to ensure financial security for the child, there was a presumption that the father of a child born in wedlock was to be considered the mother's husband. ${ }^{55}$ Since marriage was already based on the principle of monogamy, it was assumed that the mother's husband was the only one, or presumably the one with whom the mother had most sexual relations. Therefore, the legal relationship between the child and father is based on a presumption and not on a factual establishment of genetic paternity. The legal presumption of paternity for a child born in wedlock is, therefore, based on two presumptions:

a) a positive presumption that the husband of the child's mother had sexual relations with his wife, the child's mother, at the critical time, that is, at the time when conception could have occurred.

b) a negative presumption that the wife, the child's mother, did not have sexual relations with another man, that is to say, a man who is not married to her, at the critical time. ${ }^{56}$

The second paragraph of Article 113 of the FC is novel. Under the Marriage and Family Relations Act of 1976, the legal presumption of paternity extended to 300 days after the dissolution of the marriage, irrespective of the manner of dissolution (cf. Article 86 of the MFRA - thus also in the event of divorce). However, the new FC extends the legal presumption of paternity to 300 days after the dissolution of the marriage only in the case of dissolution due to the mother's husband's death. Article 114(3) of the FC, which has a twofold purpose, is also new. On the one hand, it excludes applying the legal presumption of paternity to a child born 300 days after the divorce or annulment of the marriage. The legislator was guided by the premise that 
spouses who divorce because of mutually aggravated (hostile) relations do not have sexual relations. On the other hand, it expressly stipulates that the father of a child born in a marriage entered by the child's mother within 300 days of the dissolution of the previous marriage is to be considered the mother's husband from the new marriage, irrespective of the reason for the dissolution of the previous marriage.

Article 14 of the CRS prohibits discrimination on the grounds of birth. This is further supported by Article 54(2) of the CRS, which states that children born out of wedlock shall have the same rights as children born in wedlock. However, there is a difference in creating a legal relationship between the child and father, that is, paternity. Children born out of wedlock or not born within 300 days of the dissolution of the marriage due to the father's death are not subject to the legal presumption of paternity. In such cases, paternity will have to be established, either by acknowledging paternity or by a court decision to establish paternity. In the first case, the man who gave the acknowledgement of paternity is considered as the father (subject to the conditions laid down in the FC). The consent of wills has to be given, as the child's mother must also agree to the father's acknowledgement. Whether the man who makes the acknowledgement is also the father of the child is not examined. The situation is different in the case of paternity by judicial decision, where, at the end of the court proceedings, the man whose paternity has been established in court proceedings will know that he is the father.

Acknowledging paternity is a strictly personal act. It is a unilateral declaration of will made in the prescribed form by a man who wishes to establish a family-law relationship (father-child relationship) through this declaration. It is a personal right since it is not transferable or inheritable, and it is absolute since it has an erga omnes effect. Paternity may be recognized only in the form prescribed by Article 115 of the FC. A man may acknowledge paternity at a social work center, before a registrar, in a public deed, or in a last will. Paternity may be acknowledged by a man who is capable of understanding the meaning and consequences of acknowledgement (Article. 116 of the FC).

The new Act also contains provisions on the maternity and paternity of children conceived with biomedical assistance. If the mother consented to the biomedical assistance procedure under the provisions of the Infertility Act, her maternity may not be contested (Article 133(1) of the FC). If the child was conceived with the help of a donor egg, her maternity may not be contested (Article 133(2) of the FC). The father of a child conceived with biomedical assistance is considered the mother's husband or her extramarital partner, provided that they have given their consent to the procedure according to the Infertility Act (Article 134(1) of the FC). In the case of a child conceived by biomedical assistance, the legal presumption of paternity extends to the extramarital partner (Article 134(1) of the FC). The legal presumption provided makes paternity conditional on consent to the artificial insemination procedure. If consent was not in accordance with the provisions of the Infertility Act, the legal presumption of paternity of a child born through biomedical assistance will not arise. The paternity of a child conceived by biomedical means may not be contested, except 
if the child is not conceived by a procedure of assisted reproduction (Article 134(2) of the FC). If the child was conceived with the help of a donor's sperm cell, the child's paternity may not be established (Article 134(3) of the FC).

\subsection{The mother's status}

Motherhood is the legal bond between the mother and child, established when the child is born. Starting from Article 112 of the FC, the woman who gave birth to the child is considered the child's mother. This definition is the old Roman legal presumption "mater semper certa est," which has been preserved by the new FC, although its predecessor, the MFRA, did not expressly include it. However, the presumption of motherhood was considered irrelevant. In the past, the woman who gave birth, that is, the gestational mother, was also a genetic or biological mother. However, the biological mother did not necessarily have to be the social mother, as adoption was already known, for example, in ancient Rome. Although deviations from the legal presumption of maternity may have occurred in the past (e.g., switching of a child in the hospital, deliberate switching, or tampering), there has been significant deviation from this classical legal presumption.

As biomedicine has developed, various assisted reproductive techniques have been developed. Today, assisted reproductive technologies (ART) are part of everyday life. Every sixth couple in Slovenia facing infertility-related problems. The ART that leads to a deviation from the legal presumption of motherhood is egg donation (ovum), embryo donation (embryo), or cases of surrogacy (surrogate motherhood). The latter two techniques (donations) are not allowed in Slovenia (cf. Article 13(1) and Article 7 of the Infertility Act). If the mother consented to the ART procedure under the provisions of the Infertility Act, her maternity may not be challenged (Article 133(1) of the FC). If the child was conceived with the help of a donor egg, her maternity may not be contested (Article 133(2) of the FC).

On the one hand, the development of medicine, specifically that of assisted reproduction technologies, has enabled many couples to fulfill their desire to have a child, but it has also led to so-called "split motherhood." 57 Donation of female ovum and embryo donation makes it possible for a woman to give birth to a child who is not genetically related to her. As a result, a distinction is made between genetic maternity, which is linked to the origin of the ovum or embryo, and gestational (including medical) maternity, linked to pregnancy and thus to carrying the child to term. This is particularly applicable in the case of surrogacy or surrogate motherhood. Under Article 7 of the Infertility Act, a woman who intends to give her child to a third party for free or for payment after birth is not entitled to ART in Slovenia.

The importance of maternity is already enshrined in the Slovenian CRS, as Article 53(3) of the CRS provides that the state shall protect maternity and create the necessary conditions for it. This constitutional provision on motherhood is

57 In German: gespaltene Mutterschaft. 
complemented by Article 55 of CPR, which provides that parents shall be free to decide on the birth of their children and that the state shall provide opportunities for the exercise of this freedom and create conditions that enable parents to decide on the birth of their children. The Infertility Act is relevant to this freedom. The mother of a child is considered to be a woman who gave birth to a child. It follows from the above that the child's birth is sufficient for this legal relationship to arise. Entry in the civil registry verifies this relationship. ${ }^{58}$ The child must be entered into the civil register immediately after birth. This is also defined as a fundamental right of the child in the Convention on the Rights of the Child (cf. Article 7(1) of the Convention on the Rights of the Child). This is also confirmed by Articles 4(1) and (4) of the Slovenian Civil Register Act. ${ }^{59}$

\subsection{Adoption-who can be an adoptive parent?}

According to the primacy principle, parents are the primary persons who should take care of their children. However, since circumstances may arise that make it impossible for them to care for their children (death, illness, withdrawal of parental care), an alternative form of care must be found for such children. Adoption is the best option when there is a need for permanent replacement of absent parents or their care as part of parental care. Adoption has a subsidiary character in that it will only take place when parents are unable to care for their child. Parents are the primary caregivers and have the right and obligation to care for their children.

Although adoption is the best permanent alternative form of care for children who, for various reasons, cannot be cared for by their parents, adoption should be an ultima ratio measure. Adoption is the most intrusive way of affecting the relationship between biological parents and children. When the child is adopted, parental care is permanently terminated since the adoption terminates the rights and obligations of the child toward his or her parents and other relatives, and the rights and obligations of the parents and other relatives toward the child (Article 220(1) of the FC). An exception is made if the child is adopted by the spouse or extramarital partner of one of the child's parents. Such adoption does not terminate the rights and obligations of the child toward that parent and his/her relatives, nor the rights and obligations of that parent and his/her relatives toward the child (Art. 220(2) of the FC). The purpose of adoption is to provide the child with a stable, loving, secure, and caring environment in which he or she can grow and develop harmoniously.

Article 8 of the FC provides that children enjoy the special protection of the state whenever their healthy development is endangered and when the child's best interests are required. This is the legal implementation of the constitutional provision in Article 56(3) of the CRS, which guarantees care and special protection by the state

58 Hrabar, 2007, cited in Alinčić et al., p. 133.

59 Zakon o matičnem registru: Uradni list RS, št. - official consolidated version, 67/19. See: https://bit. ly/3iAGOYW. 
for children and minors who are not cared for by their parents, who have no parents, or who are without adequate family. The situation of these children is regulated by law, specifically the FC. The state has a duty to ensure that, when such circumstances arise, the child who is a member of a vulnerable group is protected and that his or her rights and best interests are safeguarded. Adoption in this context is a measure that considers the child's ethnic, religious, cultural, and linguistic background and can ensure the continuity of the child's upbringing in a family environment (Article 20(3) of the Convention on the Rights of the Child).

In Slovenia, only a child may be adopted (Article 212 of the FC). Adoption creates the same relationship between the adoptive parents and the child as between the parents and their children. The FC, therefore, regulates only full adoption, ${ }^{60}$ which means that in the case of adoption, adoptive parents take the place of the child's biological parents.

Following the wording of Article 212 in conjunction with Article 218 of the FC, it can be concluded that adoption before the birth of the child (prenatal adoption) is not possible, since Article 212 of the FC expressly provides that "only a child may be adopted." Article 218(1) of the FC provides that "...only a child may be placed for adoption if the parents have consented to the adoption after the child's birth..." Therefore, prenatal adoption and prenatal consent to adoption are not possible.

In addition to the safeguards mentioned above for biological parents, the legislator has added a further safeguard: Parents who have given their consent to the adoption of their child after birth but before the child is eight weeks old must confirm this again after eight weeks; otherwise, the consent has no legal effect (Article 218(1) of the FC). Adoption can only occur after six months have elapsed since the consent was given (or the consent was confirmed), which still gives parents the possibility to withdraw their consent. Exceptionally, adoption may also occur before the expiry of the six months from the giving of consent (or confirmation of consent), if the court finds that this would be in the child's best interests.

The FC provides that a child may be adopted jointly by spouses or extramarital partners, that is, by a man and a woman who have been living together for a long time but have not entered into a marriage and where there are no grounds that would invalidate any marriage between them (Article 4(1) of the FC). Such legal definition favors so-called joint adoption since both spouses or extramarital partners appear in the definition of adoptive parents. This arrangement aims to provide the child with a "father" and a "mother" and thus a new family environment, representing a new beginning. On the other hand, this legal definition makes joint adoption available only to spouses or extramarital partners. Under the FC, these two partnerships can only be entered into by partners of different sex.

Following the CPA, same-sex partners have the choice of either a civil union or a de facto civil union. According to Article 213(1) of the FC, partners living in a civil union or de facto civil union cannot adopt a child together in Slovenia. The possibility

60 Lat. adoptio plena. 
of joint adoption is also expressly excluded under CPA (cf. Articles 2 and 3 of the CPA). In addition to joint adoption, Article 213 of the FC also allows for so-called single adoption, which can occur in two cases. The first case will be given when a spouse or extramarital partner adopts a child of his/her spouse or extramarital partner. In such cases, the child usually already lives with and knows the person who is the spouse or extramarital partner of his/her parent and who is already caring for him/her (step-parent adoption). However, unilateral adoption will also be carried out exceptionally for a child if it is impossible to obtain adoptive parents who are spouses or extramarital partners, and if this is in the child's best interests. In this case, such a child will also be adopted by one person. In the case of single adoption, a partner from a civil union or de facto civil union can adopt the partner's child.

In 2017, 593 applications for adoption were filed in Slovenia. In 2019 in Slovenia, there were 47 adoptions ( 17 from abroad). From the above, we can conclude that many couples in Slovenia wish to adopt a child, but there are essentially not enough children eligible for adoption. The married and cohabited couples included 21 children. However, the majority of children were adopted by the child's parent spouse or partner (24 children, step-parent adoption). There were four cases of adoption by single persons (single adoption).

As "demand exceeds supply," the waiting period of potential adopters may be greater than ten years. Therefore, some couples are ready to adopt a child from another state. Such a situation is not new since Slovenia faced a lack of "children at disposal" for adoption in former Yugoslavia. The status of that time was much more favorable, of course, as couples went for children to other federal republics and the autonomous regions, giving rise to so-called inter-federal adoptions. Today, Slovenian couples and individuals consider and undertake adoption from abroad, that is, intercountry adoption. In the past ten years, most of the children from intercountry adoption were adopted from the Russian Federation, Ukraine, and Ghana.

\section{Legal framework of the parent-children relationship}

\subsection{The content of parental control}

Parental care represents all the parents' obligations and rights to create. According to their abilities, parents should ensure that the child's full development will be possible. Parental care belongs to both parents (Article 6 of the FC). Parental care is an implementation of the constitutional provision of Article 54 of the CRS, which grants parents the right to maintain, educate, and bring up their children (Article 54(1)(1) of the CRS). Parents have the right to ensure their children's successful physical and mental development through direct care, work, and activity. Parents should take appropriate measures and actions to ensure that the child's well-being 
will be realized. Parents shape what is best for their children according to their ideas, wishes, and expectations. "Parental care" is a new legal concept that has replaced the concept of "parental rights." Thus, the concept of parental care also reaffirms the child-centered approach that the entire FC pursues and builds on.

Following the principle of priority, parents have primary and equal responsibility for the child. Parental care belongs to both parents jointly and represents the whole of the parents' obligations and rights. According to their respective capacities, the parents shall ensure everything that the child needs for full development (Article 6 of the FC). This provision is supplemented by Article 136(1) of the FC, which states that parental care comprises the obligations and rights of the parents related to the care of the child's life and health, upbringing, protection and care, supervision of the child and care for his or her education, and the obligations and rights of the parents relating to the representation and maintenance of the child and the management of the child's property. Parental care may be limited or withdrawn from one or both parents only under the conditions laid down by the FC (Article 136(2) of the FC).

Parents' rights and obligations are set out not only in the FC, but also in other legal acts. One such legal act is the Personal Name Act ${ }^{61}$ (PNA). The PNA stipulates that parents must determine a personal name for their child and register it with any administrative unit no later than 30 days after the child's birth (Article 6(1) of the PNA). The child's personal name shall be determined by the parents by mutual agreement, unless one of the parents is unknown, no longer alive, or unable to exercise parental care. In this case, the other parent determines the personal name of the child. The child may take the surname of one or both parents, or the parents may give the child a different surname. However, in the event that the child's parents are no longer alive or cannot exercise parental care, the child's personal name is determined by the person entrusted with the child's care, in agreement with the competent social work center (Article 7 of the PNA). Therefore, the child has the right to a personal name (Article 7(1) of the Convention on the Rights of the Child). The basic characteristics of a personal name are that it enables the individualization of a specific natural person. It has a non-property character and is (in principle) non-transferable. The right to a name is now included in the protection system for fundamental human rights.

Parents exercise parental care jointly and consensually. This fundamental principle applies both while they live together, and if they are no longer living together or will no longer be living together. Despite separation, parental care still belongs to both parents, unless it has been limited or withdrawn. Parents are (usually) the most important people in the child's life, influencing the child's present and future life through their direct or indirect actions, thoughts, lifestyles, etc. The patterns that parents have passed on to their children during their childhood are patterns that children themselves often follow when they grow up (e.g., child-rearing, world and religious views). Parents have obligations and rights as part of their parental 
responsibility toward their children. These rights also place them in a privileged position vis-à-vis third parties. Parents have primary obligations and rights with respect to their children. Only if they fail to exercise parental care for the child's best interest may other persons take over certain rights of parental care (e.g., care and upbringing in the case of foster placement). Parental obligations correlate with children's rights. ${ }^{62}$

If the parents do not or will no longer live together, they must agree on the care and upbringing of their joint children following their child's best interests. Separation can be caused by divorce or annulment, the break-up of an extramarital union or civil union, or where the parents have never lived together but have a child in common. Following the principle of autonomy, parents should have the best knowledge of the circumstances, subjective and objective, relevant to regulating the relationship to the common child in the event of their separation. The parents can thus also settle by mutual agreement the question of the care and upbringing of the joint children over whom they have parental care.

If parents cannot reach an agreement on their own, they are assisted by the social work center or, if they wish, by mediators. When the court dissolves the marriage based on a divorce petition filed by one of the spouses, it also decides on the custody, upbringing, and maintenance of the children living together and on their contact with their parents (Article 98(2) of the FC). However, before deciding on the above, the court must determine how the child's best interests will be safeguarded (Article 98(3) of the FC). If parents agree on the custody of their children, they may propose a court settlement. The court will examine the content of the proposal for a court settlement ex officio. The interests of the children are at stake and require closer supervision of consensual agreement.

The court will follow the parents' agreement if it finds that it is in the child's best interests and that their rights are safeguarded. However, if the court finds that the agreement is not in the child's best interests, it will reject the agreement (Article 138(2) of the FC). Parents may amend or modify the agreement accordingly. If they do not do so or have not reached an agreement, the court will decide only on the custody of the joint children over whom the parents have parental care. In doing so, the court may also decide beyond the claims (extra petitum) or even without any claims being raised (ultra petitum).

Maintenance enables the child to meet his or her daily needs in terms of food, clothing, education, leisure time, etc. As long as the parents live together, both parents usually contribute to the child's maintenance within the framework of the existing community. However, where the parents do not or will not live together, the parent who does not live with the child must contribute to the child's maintenance. In this case, following the principle of autonomy, parents can make arrangements for maintenance. In particular, it is understood that they agree on the amount of maintenance and payment method. The parents know the child's needs and capacity 
to determine the amount of maintenance. The parents are free to agree on how to share the maintenance burden between them. Despite the possibility of autonomous decision-making, parents must regard the child's best interests, which the court must verify of its own motion. If parents cannot reach an agreement themselves, they will be assisted by the social work center or, if they so wish, mediators. However, if the parents cannot reach an agreement on the maintenance of their joint children, the court will decide on maintenance.

The principle of family solidarity implies an obligation for the spouse or extramarital partner of the partner (step-parent) to support the child (stepchild) of his/her spouse or extramarital partner unless the child's parent is capable of supporting the child (Article 187(1) of the FC). This maintenance obligation is of a subsidiary nature, since it will only be imposed if the child cannot be maintained by the parents. The maintenance obligation of a spouse or extramarital partner of the child's parent will cease with the dissolution of the marriage or extramarital union with the child's parent unless the dissolution of marriage is a result of the death of the child's mother or father. In this case, the surviving spouse or extramarital partner (step-parent) must support the child if they were living together at the time of death (Article 187(2) of the FC).

\subsection{The child's right to freedom of conscience and religion, the child's right to their own national identity (religion, language, culture, homeland, home)}

Article 41(3) of the Slovenian CRS gives parents the right to provide their children with religious and moral upbringing following their beliefs. The religious and moral guidance given to children must be appropriate to their age and maturity and be consistent with their free conscience, religious beliefs, and other beliefs or convictions. Article 10 of the Freedom of Religion Act $^{63}$ complements the CRS by giving parents the right to educate their children following their religious beliefs. In doing so, they must respect the child's physical and mental integrity. However, a child who has reached the age of 15 has the right to make his or her own decisions relating to religious freedom.

The social work center must find an adoptive parent for the child who, in its opinion, can best care for the child. In doing so, it shall also take into account the child's previous upbringing, ethnic, religious, or cultural background, if any. 


\section{Bibliography}

ALINČIĆ, D. ET AL. (2007) Obiteljsko pravo, Zagreb: Narodne novine.

Coester-WAltJen, D. 'Family Forms and Parenthood in Germany' in BüCHLER, A., KelLeR, H. (eds.) (2016). Family Forms and Parenthood: Theory and Practice of Article 8 ECHR in Europe. $1^{\text {st }}$ Cambridge: Intersentia.

Cretney, S. (2000) Family Law. $1^{\text {st }}$ London: Sweet \& Maxwell.

DRAŠKIĆ, M. (2016) Komentar Porodičnog zakona. $1^{\text {st }}$ Beograd: Službeni glasnik.

EUROPEAN UNION (2020) The Rights of LGBTI People in the European Union [Online]. Available at: https://bit.ly/3a8mBoC (Accessed: 23 March 2021).

EUROSTAT (2021) Fertility Indicators [Online]. Available at: https://bit.ly/3uHibyj (accessed: 31 March 2021).

KonČinA Peternel, M. (1998) Pomoč otrokom, ko starši odpovedo. Ljubljana: Znanstveno in publicistično središče.

KovAČEK STANIĆ, G. (2014) Porodično pravo: partnersko, dečje i starateljsko pravo. $5^{\text {th }}$ Novi Sad: Univerzitet u Novom Sadu, Pravni fakultet, Centar za izdavačku delatnost.

KRALJIĆ, S. (2017) 'Same-Sex Partnerships in Eastern Europe: Marriage, Registration, or No Regulation?' in Boele-Woelki, K., Fuchs, A. (eds.) Same-sex Relationships and Beyond: Gender Matters in the EU (European Family Law Series, 42). $3^{\text {rd }}$ Cambridge: Intersentia.

KRALJIĆ, S. (2019) Družinski zakonik s komentarjem. $1^{\text {st }}$ Maribor: Poslovna založba.

KRALJIĆ, S., KRIŽNIK, A. (2021). Pravni izzivi skrbništva. Maribor: WD Založba.

MLAdENOviĆ, M. (1981) Porodično pravo, Knjiga II. $1^{\text {st }}$ Beograd: Privredna štampa.

OECD (2019) SF3.1: Marriage and Divorce Rates. Available at: https://bit.ly/3BdG2s6 (Accessed: 31 March 2021).

OECD (2020) SF2.4: Share of Births Outside of Marriage [Online]. Available at: https://bit. ly/3AfkiKW (Accessed: 31 March 2021).

SURS (2020) Sklenitve in razveze zakonskih zvez, Slovenija, 2019 [Online]. Available at: https:// bit.ly/3uIvy1x (Accessed: 31 March 2021).

SURS (n.d.) Osnovni podatki in kazalniki o razvezah zakonskih zvez, Slovenija, letno [Online]. Available at: https://bit.ly/3iuAIcf (Accessed: 31 March 2021). 